Jurnal Ilmu Budaya, Vol. 16, No. 2 Februari Tahun 2020

\title{
CINDERELLA: MENDOBRAK CITRA PEREMPUAN DALAM LIRIK LAGU TATA YOUNG
}

\author{
Essy Syam ${ }^{1}$, Mita Rosaliza ${ }^{2}$ \\ Universitas Lancang Kuning ${ }^{1}$ \\ Universitas Riau ${ }^{2}$ \\ essy_fib@yahoo.com
}

\begin{abstract}
This writing analyzes a lyric of a song entitled Cinderella, sung by Tata Young, a Thai-American singer in her album, I Believe which was released in 2004. The analysis focuses on how the lyric dismantles the images of women. In this case, it dismantles the images of women found in the works of fairytales which present women with certain images such as weak, passive, submissive, dependent and other weakening images. Thus, this lyric presents the images of women different from those found the fairytales.
\end{abstract}

Keywords: Cinderella, Tata Young, image, women.

\section{PENDAHULUAN}

Lirik lagu merupakan karya yang diciptakan dengan indah karena sebuah lagu selalu mengekspresikan perasaan penulisnya yang menuangkan emosinya dengan rangkaian kata-kata yang indah walaupun lagu itu menggambarkan kesedihan. Pada dasarnya sebuah lagu diciptakan untuk menghibur orang yang mendengarnya. Selain bertujuan menghibur, sebuah lagu juga memiliki pesan yang ingin disampaikan. Pesan yang disisipkan dalam sebuah lagu memiliki makna yang perlu diinterpretasikan untuk memaknainya dengan utuh.

Dalam memahami makna sebuah lagu, deretan kata dalam lagu tersebut menjadi data utama yang akan dikaji. Seperti halnya puisi, sebuah lagu menyampaikan pesannya 
Jurnal Ilmu Budaya, Vol. 16, No. 2 Februari Tahun 2020

dengan pilihan kata yang penuh

makna yang merupakan kekuatan

pada lagu tersebut.

Sebuah lagu tidak hanya merupakan bentuk ekspresi penciptaya, tapi juga dapat menjadi cerminan bagaimana persepsi penciptanya terhadap suatu topik yang ingin disampaikannya. Salah satu topik yang menarik, yang diangkat dalam kajian ini, adalah topik tentang citra perempuan, yang merupakan suatu konstruksi dalam masyarakat. Citra perempuan dikonstruksi lewat berbagai media. Kisah-kisah dalam fairy tales merupakan salah satu sarana mengkonstruksi citra perempuan tersebut, dimana perempuan dilabeli dengan label atau imej yang mempertegas posisinya sebagai sosok yang perlu dilindungi, diselamatkan dan dijaga. Di saat yang sama, sebaliknya, laki-laki ditempelkan label atau citra yang menempatkannya sebagai sosok yang menjadi pahlawan penyelamat bagi perempuan.
Terkait dengan hal di atas, lirik lagu Cinderella, yang dinyanyikan oleh Tata Young menampilkan citra perempuan yang berbeda dari citra perempuan yang diekspresikan dalam kisah-kisah fairy tales. Sejalan dengan hal itu, kajian ini akan menyorot bagaimana lirik lagu Cinderella ini membongkar citra perempuan yang terdapat dalam fairy tales tersebut.

\section{KONSEP}

\section{A. Citra dan Stereotipe}

Citra atau imej dapat pula dimaknai sama dengan stereotipe yang merupakan suatu tindakan memberi sifat tertentu terhadap seseorang atau kelompok orang. Pemberian sifat ini dapat bersifat negatif maupun positif yang didasari dari persepsi seseorang terhadap pihak lain. Persepsi ini dapat terbentuk dari sikap yang telah lebih dahulu ada. Karena itulah citra atau stereotipe ini cendrung melakukan penciptaan label. Narwoko dan Suyanto dalam Saguni (Jurnal 
Jurnal Ilmu Budaya, Vol. 16, No. 2 Februari Tahun 2020

Musawa, 2014: 201) lebih jauh

menjelaskan babwa penciptaan label

terhadap suatu pihak atau kelompok

dapat berakibat merugikan pihak tersebut. Dalam hal ini citra dapat saja terbentuk dalam upaya memberikan ciri terhadap suatu etnik, misalnya, etnis jawa dicitrai sebagai masyarakat yang lamban dan penurut tapi juga ulet, etnis batak dicitra dengan citra keras kepala, kasar, dan straight to the point, dan citra-citra lainnya yang melabeli etnis-etnis tertentu. Citra yang terbentuk ini, lalu digeneralisasi dan dijadikan pegangan dalam berinteraksi dengan masyarakat dari etnis tertentu, padahal label yang ditempelkan pada etnis tersebut bisa jadi benar bisa juga salah.

Stereotipe dipahami sebagai tidakan yang mengeneralisasi sesuatu yang relatif tetap terhadap seseorang atau kelompok orang. Dalam prakteknya, pemahaman ini difokuskan pada karakteristik negatif dan tidak menguntungkan, walaupun ada juga yang memasukkan konsep stereotipe yang positif.

Istilah stereotipe berasal dari bahasa Yunani, dari kata stereos yang berarti solid, dan tupos yang berarti citra atau kesan. Pada awalnya stereotipe adalah suatu rencana bentukan, dan ketika bentukan itu sudah terbentuk, maka sulit untuk diubah. Istilah ini, lalu menuntun pada persepsi yang mencitrakan kelompok tertentu yang membedakannya dengan kelompok yang lain. Hal ini juga berlaku dalam menempelkan stereotipe dengan kualitas tertentu pada laki-laki dan membedakannya dengan kualitas lainnya yang ditempelkan pada perempuan (Kuper dan Kuper, 2008: 1054-1055).

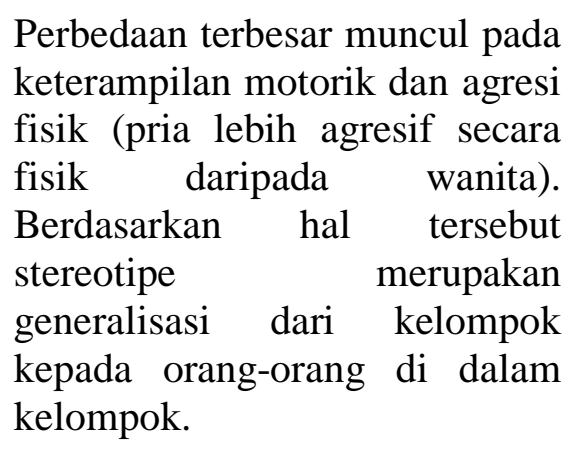

Perbedaan terbesar muncul pada keterampilan motorik dan agresi fisik (pria lebih agresif secara fisik daripada wanita). Berdasarkan hal tersebut stereotipe merupakan generalisasi dari kelompok kelompok. 
Jurnal Ilmu Budaya, Vol. 16, No. 2 Februari Tahun 2020

Stereotipe adalah pemberian sifat tertentu terhadap sesorang berdasarkan kategori yang bersifat subjektif hanya karena dia berasal dari kelompok lain. Stereotipe didasarkan pada penafsiran yang kita hasilkan atas dasar cara pandang dan latar belakang budaya (Saguni, Jurnal Musawa, 2019: 199-204).

Dalam interaksi antara laki-laki dan perempuan penciptaan citra dan proses melabeli menempatkan perempuan dalam posisi yang kurang menguntungkan karena perempuan dilabeli dengan label-label yang mempertegas kelemahannya dan di saat yang sama mempertegas kekuatan laki-laki. Seorang perempuan dipersepsikan kurang mampu mengerjakan pekerjaan-pekerjaan yang memerlukan kekuatan fisik atau yang memiliki tantangan yang besar sedangkan laki-laki dipersepsikan kurang mampu mengerjakan pekerjaan-pekerjaan yang bersifat melayani. Label ini mempertajam perbedaan laki-laki dan perempuan dengan konsep perbedaan gender.
Klasifikasi peran gender melibatkan anak laki-laki dan anak perempuan dalam hal kelompok sifat-sifat kepribadian. Di masa lalu, seorang anak laki-laki yang diurus dengan baik seharusnya mandiri, agresif, dan kuat. Seorang wanita yang diurus dengan baik seharusnya tidak mandiri, memiliki sifat mengasuh, dan tidak tertarik pada kekuatan. Pada saat yang sama, secara keseluruhan, karakteristik maskulin dianggap sehat dan baik oleh masyarakat, sementara karakteristik feminin dianggap tidak menyenangkan (Saguni, Jurnal Musawa, 2019: 2005).

Jadi, proses melabel, menciptakan citra atau imej dan penciptaan stereotipe merupakan suatu ciptaan atau konstruksi masyarakat yang secara terus menerus disosialisasikan dengan berbagai versi dan berbagai cara. Salah satu cara yang dianggap sangat efektif adalah melalui internalisasi sejak kecil ketika "orang tua membeli lebih banyak buku matematika dan ilmu pengetahuan alam serta mainan untuk anak laki-laki mereka daripada untuk 
Jurnal Ilmu Budaya, Vol. 16, No. 2 Februari Tahun 2020

anak perempuan, mereka mengatakan

bahwa anak laki-laki mempunyai bakat matematika yang lebih baik daripada anak perempuan dan anak laki-laki lebih sesuai untuk berkarier dalam bidang matematika" (Saguni, Jurnal Musawa, 2019: 212). Sedangkan anak perempuan cendrung diberikan permainan yang mengasah sikap melayani seperti boneka dan kitchen set. Lewat internalisasi, seorang perempuan dan laki-laki memahami perbedaan mereka dan menempatkan diri mereka dalam persepsi yang sudah terbentuk tadi.

Dalam sebagian besar masyarakat upaya penciptaan stereotipe membuat masyarakat percaya bahwa laki-laki dan perempuan memiliki kualitas yang berbeda, yang dimiliki masing-masing pihak sebagi suatu pembeda di antara keduanya. Seorang aktivis Amerika Kate Millet mengungkapkan bagaimana stereotipe dan kualitas laki-laki dan perempuan dikonstruksi melalui suatu proses stereotyping, seperti yang dijelaskan oleh Eisenstein (dalam Syam, Jurnal Ilmu Budaya, 2005: 4)

For female "normal" meant passive, while for male, it meant active. Men had instrumental traits: they are tenacious, aggressive, curious, ambitious, planful, responsible, original and competitive. Women had expressive traits: they are affectionate, obedient, responsive to sympathy, approval, careful, kind and friendly.

\section{B. Lirik Lagu dan Budaya Populer}

Lirik lagu merupakan salah satu bentuk budaya populer akhir abad ke 20, yang merupakan produk budaya populer yang sangat populer di dunia. Sebagai suatu produk budaya populer, lirik lagu dapat digunakan sebagai sarana menyampaikan pesan bahkan dapat digunakan untuk mempengaruhi cara berpikir seseorang. Hal ini dimungkinkan karena ketika seseorang menikmati suatu produk populer seperti lagu ini, ia tidak sedang menggunakan daya kritisnya. 
Jurnal Ilmu Budaya, Vol. 16, No. 2 Februari Tahun 2020

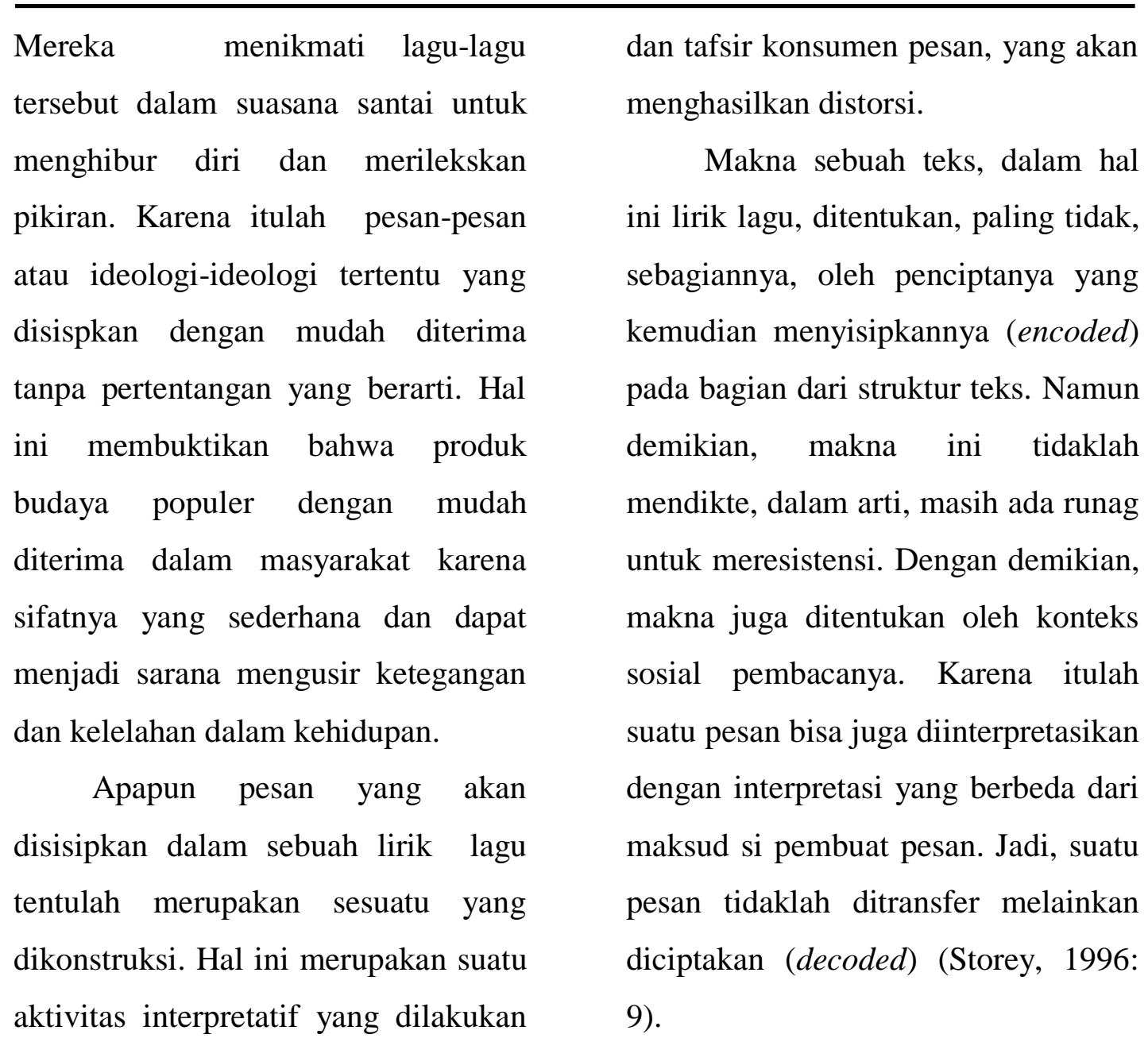
oleh pendengar atau penikmat lirik lagu tersebut. Masyarakat yang meresepsi serta menginterpretasinya tidak bersifat homogen, melainkan terbentuk dari berbagai kelompok dan kepentingan, oleh sebab itu selalu terdapat kesenjangan antara aspekaspek produksi dan proses-proses

\section{CINDERELLA}

Cinderella merupakan judul lirik lagu yang dinyanyikan oleh Tata Young, yang bernama asli Amita Marie, seorang penyanyi, aktris, model dan penari keturunan Thailand Amerika. Lagu Cinderella ini dirilis 
Jurnal Ilmu Budaya, Vol. 16, No. 2 Februari Tahun 2020

tahun 2004 yang terdapat dalam album I Believe.

\section{Cinderella}

When I was just a little girl

My mama used to tuck me into bed

And she read me story

It always was about a princess in distress

And how a guy would save her and end up with glory

I'd lie in bed and think about the person that I wanted to be

Then one day I realized the fairy tale

life wasn't for me.

I don't wanna be like Cinderella

Sitting in a dark old rusty cellar

Waiting for somebody to come and set me free.

I don't wanna be like Snow White

Waiting for a handsome prince to come and save me

On a horse of white, unless we're riding side by side

Don't want to depend on no-one else

I'd rather rescue myself

Someday, I'm gonna find someone

Who wants my soul, heart, and mind

Who's not afraid to show that he loves

me

Somebody who will understand I'm happy just the way I am

Don't need anybody taking care of me.
I will be there for him just as strong as he, will be there for me

When I give myself then it has got to be an equal thing

I can slay my own dragon

I can dream my own dreams

My knight is shining armour is me

So I'm gonna set me free

IV. PEMBAHASAN

A. Citra Perempuan Fairy Tales Dalam Lirik Cinderella

Dalam lirik lagu Cinderella ini citra perempuan yang ditampilkan mengaitkannya dengan kisah (fairy tale) Cinderella dan Snow White, pada satu sisi dan citra perempuan yang berbeda dari kedua fairy tales itu yang merupakan upaya membongkar atau mendobrak pencitraan perempuan yang sudah terbentuk sebelumnya lewat fairy tales sejenis. Dalam fairy tales, citra perempuan yang terbentuk adalah perempuan yang dependen dan pasif.

\section{Dependen}

Citra perempuan yang dependen, yang menggantungkan 
Jurnal Ilmu Budaya, Vol. 16, No. 2 Februari Tahun 2020

hidupnya pada orang lain, dalam hal

ini khususnya ketergantungan

perempuan pada laki-laki, terlihat dari

kisah-kisah yang dibacakan ibu

kepada putrinya sebagai cerita

pengantar tidur. Kisah-kisah tersebut

menggambarkan bagaimana seorang

putri mengalami kesulitan dalam

hidupnya, "When I was just a little

girl, my mama used to tuck me into

bed and she read me story. It always

was about a princess in distress"

(Young, line 1-4). Sang putri lalu

ditolong oleh seseorang yang

kemudian membawanya pada

kehidupan yang membahagiakan,

"and how a guy would save her, and end up with glory" (Young, 2004: 5-

$6)$.

Lebih rinci lagi, lirik lagu ini

menyebutkan kisah Cinderella yang menunggu seseorang untuk menyelamatkannya dari kesulitan hidupnya, "waiting for somebody to come and set me free" (Young, 2004: 8-12). Lalu selain Cinderella, lirik ini juga secara spesifik menyebutkan
Snow White yang menanti kedatangan pangeran tampan untuk menyelamatkannya, “... waiting for a handsome prince to save me" (Young, 2004: 11-12).

Dari kisah fairy tales Cinderella dan Snow White yang disebutkan oleh lirik lagu ini terlihat citra perempuan yang dependen, yang menggantungkan nasibnya pada orang lain, yang mengharapkan dan menunggu orang lain untuk menyelamatkan dirinya dan tidak berusaha untuk menyelamatkan dirinya sendiri. Citra yang terbentuk ini dapat melemahkan semangat juang perempuan untuk berdiri sendiri sehingga bagi perempuan yang menghayani citra ini, akan dengan sabar menunggu pertolongan dalam mengatasi masalah hidupnya dan tidak mengandalkan dirinya sendiri dalam mengatasi kesulitan hidupnya sehingga citra ini dapat menciptakan perempuan-perempuan yang lemah daya juangnya. Citra ketergantungan perempuan terhadap orang lain juga 
Jurnal Ilmu Budaya, Vol. 16, No. 2 Februari Tahun 2020

dapat membuat perempuan kurang menyadari potensi yang ada pada dirinya sehingga perempuan kurang memkasimalkan potensi tersebut. Dengan demikian, ketergantungan perempuan kepada orang lain akan terus terjadi. Walaupun dalam kehidupan tidak ada manusia yang dapat hidup sendiri karena manusia sebagai makhluk sosial selalu berhubungan dan membutuhkan orang lain. Namun ini tidak dimaknai bahwa seseorang tidak dapat memperjuangkan hidupnya. Bukankah seseorang harus berjuang semaksimal mungkin untuk mendapatkan kehidupan yang baik sehingga untuk mencapainya, seseorang tidak dapat hanya mengandalkan orang lain karena setiap manusia dibekali kekuatan dan kemampuan tertentu dalam menjalani kehidupannya. Jadi, seseorang harus memaksimalkan potensinya. Pencitraan perempuan yang menggantungkan hidupnya pada pertolongan orang lain, sekali lagi, menempatkan perempuan pada posisi yang kurang menguntungkan karena perempuan kemudian dianggap sebagai sosok yang lemah dan tidak berdaya.

\section{IV.1.2. Pasif}

Selain citra perempuan yang dependen, dalam fairy tales terlihat juga citra perempuan yang pasif. Hal ini ditemukan dalam lirik lagu pada baris ke 8-12 yang memperlihatkan bahwa baik Cinderella maupun Snow White adalah sosok yang pasif karena kedua sosok ini tidak melakukan tindakan apapun untuk mengubah nasib. Keduanya digambarkan hanya menunggu pangeran tampan untuk menyelamatkan mereka. Cinderella duduk di dalam gudang tua, gelap dan berkarat menunggu seseorang untuk membebaskannya, “I don't wanna be like Cinderella, sitting in a dark old rusty cellar, waiting for somebody to come and set me free". Baris ini menggambarkan kepasifan Cinderella menunggu kedatangan seseorang untuk membebaskannya (Young, 
Jurnal Ilmu Budaya, Vol. 16, No. 2 Februari Tahun 2020

2004: 8-12). Begitu pula halnya dengan Snow White yang menunggu pangeran tampan untuk menyelamatkannya, "I don't wanna be like Snow White, waiting for a handsome prince to come and save me" (Young, 2014: 11-12). Bagi perempuan yang menghayati citra yang dikonstruksi ini, akan menuntun perempuan tersebut untuk menjadi kurang bersemangat sehingga dapat melemahkan daya juangnya.

\section{IV.2. Pembongkaran Citra Perempuan dalam Lirik} Cinderella

Citra perempuan yang terbentuk dalam lirik lagu Cinderella ini membongkar citra yang dibentuk dalam kisah fairy tales tentang Cinderella, Snow White dan kisahkisah dalam fairy tales lainnya yang memiliki tema yang sama. Karena itulah citra perempuan dalam lirik lagu ini menampilkan citra yang bertolak belakang dengan citra perempuan yang ditemukan dalam fairy tales. Dalam lirik lagu ini, perempuan dicitrakan sebagai sosok yang aktif, independen dan kuat.

\section{IV.2.1. Aktif}

Lirik lagu Cinderella ini memperlihatkan ekspresi ketidaksetujuan penulisnya untuk menggantungkan hidupnya pada orang lain. Dengan mengekspresikan ketidaksetujuannya itu lirik lagu ini memperlihatkan sosok perempuan tidak menunggu dengan pasif namun secara aktif memperjuangkan nasibnya sendiri. Baris 23-26 mempertegas hal ini, "I can slay my own dragon, I can dream my own dream, My knight in shinning armour is me, so I'm gonna set me free“ (Young, 2004: 23-26). Baris-baris ini mendeskripsikan perjuangan perempuan secara aktif untuk memperjuangkan hidupnya. Baris " $I$ can slay my own dragon" mengimplikasikan bahwa perempuan mengatasi tantangan hidupnya sendiri, "I can dream my own dream" 
Jurnal Ilmu Budaya, Vol. 16, No. 2 Februari Tahun 2020

$\begin{array}{ll}\text { mengekspresikan } \quad \text { perempuan } & \text { be like Cinderella" (Young, 2014: 8) } \\ \text { menentukan impian hiudpnya sendiri } & \text { dan "I don't wanna be like Snow } \\ \text { dan menjadikan impoiannya menjadi } & \text { White" (Young. 2014: 11) }\end{array}$
kenyataan. "My knight in shinning menggambarkan bahwa perempuan armour is me" menunjukkan bahwa itu tidak ingin menjadi seperti perempuan itu sendiri yang berjuang Cinderella dan Snow White yang dengan tangannya sendiri, ia sendiri menggantungkan hidupnya dan yang menjadi pahlawan dalam menunggu kedatangan sang dewa hidupnya. Dan baris terakhir "so I'm penyelamat. Perempuan dalam lirik gonna set me free" menyiratkan lagu ini tidak ingin menggantungkan perempuan itu membebaskan dirinya sendiri. Jadi, baris-baris ini memperlihatkan bahwa perempuan itu sosok yang aktif menentukan hidupnya sendiri.

\section{IV.2.2. Independen}

Selain menampilkan sosok perempuan yang aktif, lirik lagu ini juga mengekspresikan sosok perempuan yang independen, yang tidak menggantungkan hidupnya pada orang lain. Lirik ini mengekspresikan bagaimana perempuan ini tidak mau bertindak seperti Cinderella dan Snow White yang menggantungkan nasibnya pada orang lain. Baris “I don't wanna hidupnya pada orang lain. Dengan tegas baris “Don't want to depend on no one else" (Young, 2014: 14) mengungkapkan ketidakinginannya untuk bergantung pada orang lain.

Lebih lanjut lagi, sosok yang independen dan mandiri ini, dipertegas dengan baris “Don't need anybody taking care of me." Baris ini mempertegas kemandiriannya yang tidak memerlukan orang lain untuk mengurus dirinya karena perempuan ini mampu mengurus dirinya sendiri.

Selain itu, sosok perempuan dalam lirik ini, mempertegas kemandiriannya dengan mengungkapkan dengan tegas 
Jurnal Ilmu Budaya, Vol. 16, No. 2 Februari Tahun 2020

perempuan ini mengatakan ia tidak memerlukan orang lain untuk menyelamatkannya bila ia berada dalam situasi yang berat. Baris " $I$ don't wanna be like Snow White, waiting for a handsome prince to come and save me" ini memperlihatkan hal itu.

\section{2. 3. Kuat}

Citra perempuan lainnya yang ditampilkan lirik lagu ini adalah citra perempuan yang kuat. Kekuatan perempuan ini diekspresikan dalam baris-baris yang menyiratkan kekuatannya. Kekuatannya itu digambarkan dengan kalimat yang menunjukkan kemampuannya secara fisik maupun mental. Baris "I can slay my own dragon," dapat dimaknai kekuatan yang bersifat fisik maupun mental. Bila perempuan itu mampu membunuh naga. Kemampuan membunuh ini dimaknai kekuatan fisik maupun mental. Lebih lanjut, baris "My knight in shinning armour is me," menunjukkan dengan kekuatannya, ia menjadi pahlawan dengan baju perangnya menghadapi musuh. Dalam hal ini, kalimat ini lebih mempertegas kekuatan fisik.

Jadi, perempuan dicitrakan dengan citra yang meyiratkan kekuatannya dalam menjalani hidupnya sehingga dengan kekuatannya itu ia mampu berdiri tegak menyelesaikan semua persoalan hidupnya.

\section{SIMPULAN}

Lirik lagu Cinderella yang dinyanyikan oleh Tata Young mendobrak citra perempuan yang secara general ditampilkan dalam berbagai kisah, khususnya, dalam fairy tales. Dalam sebagian besar fairy tales perempuan dicitrakan sebagai sosok yang dependen, tergantung pada orang lain dan sosok yang pasif. Citra ini dikonstruksi untuk membuat perempuan menghayati citra ini sehingga menerima kondisi yang 
Jurnal Ilmu Budaya, Vol. 16, No. 2 Februari Tahun 2020

menempatkannya pada situasi yang melemahkan.

$$
\text { Lirik lagu Cinderella }
$$

membongkar citra yang diekspresikan dalam fairy tales. Dalam lirik lagu ini perempuan dicitrakan sebagai sosok yang aktif, independen dan kuat. Dengan citra ini, perempuan berdiri di atas kakinya sendiri, menjadi penentu hidupnya sendiri dan berjuang untuk dirinya sendiri. Dengan citra ini perempuan tidak lagi dianggap sebagai sosok yang lemah, sehingga akan menimbulkan rasa percaya diri perempuan untuk menentukan hidupnya sendiri.

\section{DAFTAR PUSTAKA}

Kuper, Adam dan Jessica Kuper. 2008. Ensiklopedi Ilmu-Ilmu Sosial. Jakarta: PT. Raja Grafindo Persada.

Storey, John. 1993. An Introduction Guide to Cultural Theory and Popular Culture. Great Britain: Harvester Wheatleaf

Saguni, Fatimah. 2019. Pemberian Stereotipe Gender. diakses dari https://media.neliti.com/media/p ublications/138333-ID- pemberian-stereotypegender.pdf.

Syam, E. 2005. Cinderella: Sosialisasi Stereotipe Laki-laki dan Perempuan, Pekanbaru: Jurnal Ilmu Budaya, Fakultas Ilmu Budaya, Unilak.

Young, Tata. 2004. Cinderella, dalam album "I Believe". 